\title{
STEVENS JOHNSON SYNDROME
}

\author{
Julia Fitriany $^{1}$, Fajri Alratisda ${ }^{2}$ \\ ${ }^{1}$ SMF Ilmu Kesehatan Anak, Fakultas Kedokteran, Universitas Malikussaleh, Aceh, Indonesia \\ ${ }^{2}$ Program Studi Profesi Dokter, Fakultas Kedokteran, Universitas Malikussaleh, Aceh, Indonesia \\ Corresponding author : fajrialratisda67@gmail.com
}

\begin{abstract}
Abstrak
Stevens Johnson Syndrome (SJS) merupakan suatu sindroma atau kumpulan gejala yang mengenai kulit, selaput lendir, dan mata dengan keadaan umum yang bervariasi dari ringan sampai berat. Penyakit ini bersifat akut dan pada bentuk yang berat dapat menyebabkan kematian, oleh karena itu penyakit ini merupakan salah satu kegawatdaruratan penyakit kulit. Sindroma ini merupakan salah satu contoh immune-complex-mediated hypersensitivity, atau yang juga disebut reaksi hipersensitivitas tipe III, di mana kejadiaannya dapat diinduksi oleh paparan obat, infeksi, imunisasi, maupun akibat paparan fisik lain kepada pasien. Stevens Johnson Syndrome berisiko menimbulkan kematian, perawatan dan pengobatan pasien SJS sangat membutuhkan penanganan yang tepat dan cepat. Adapun terapi yang bisa diberikan antara lain perawatan terhadap kulit dan penggantian cairan tubuh, perawatan terhadap luka, serta perawatan terhadap mata. Kelangsungan hidup pasien Stevens Johnson Syndrome bergantung pada tingkat pengelupasan kulit, di mana apabila pengelupasan kulit semakin meluas, maka prognosisnya dapat menjadi semakin buruk. Selain itu, variabel lain seperti dengan usia penderita, keganasan penyakit tersebut, denyut jantung, kadar glukosa, kadar BUN dan tingkat bikarbonat juga dapat mempengaruhi kelangsungan hidup pasien.
\end{abstract}

Kata Kunci : hipersensitivitas; kulit; mata; selaput-lendir; syndrome 


\title{
STEVENS JOHNSON SYNDROME
}

\begin{abstract}
Stevens Johnson Syndrome (SJS) is syndrome or collection of symptoms that affect the skin, mucous membranes, and eyes with general conditions that vary from mild to severe. This disease is acute and in severe forms can cause death, therefore this disease is one of the emergency skin diseases. This syndrome is one example of immune-complex-mediated hypersensitivity, or what is also called type III hypersensitivity reaction, where the incidence can be induced by drug exposure, infection, immunization, or due to other physical exposure to the patient. Stevens Johnson Syndrome is at risk of causing death, treatment and treatment of SJS patients desperately need proper and fast treatment. The therapies that can be given include skin care and body fluid replacement, wound care, and eye care. The survival of Stevens Johnson Syndrome patients depends on the level of exfoliation, where when skin exfoliation expands, the prognosis can get worse. In addition, other variables such as the age of the patient, the severity of the disease, heart rate, glucose levels, BUN levels and bicarbonate levels can also affect the survival of patients.
\end{abstract}

Keywords : hypersensitivity; skin; eye; mucous membrane; syndrome 


\section{PENDAHULUAN}

Stevens Johnson Syndrome (SJS) pertama diketahui pada 1922 oleh dua dokter, dr. Stevens dan dr. Johnson, pada dua pasien anak laki-laki. Namun dokter tersebut tidak dapat menentukan penyebabnya Stevens Johnson Syndrome dijelaskan pertama kali pada tahun 1922, Stevens Johnson Syndrome merupakan hipersensitivitas yang dimediasi kompleks imun yang merupakan ekspresi berat dari eritema multiforme. Stevens Johnson Syndrome (SJS) (ektodermosis erosiva pluriorifisialis, sindrom mukokutaneaokular, eritema multiformis tipe Hebra, eritema multiforme mayor, eritema bulosa maligna) adalah sindrom kelainan kulit berupa eritema, vesikel, bula, dapat disertai purpura yang mengenai kulit, selaput lendir orifisium, dan mata dengan keadaan umum bervariasi dari baik sampai buruk. ${ }^{1}$

Sindrom Stevens-Johnson merupakan kumpulan gejala (sindrom) berupa kelainan dengan ciri eritema, vesikel, bula, purpura pada kulit pada muara rongga tubuh yang mempunyai selaput lendir serta mukosa kelopak mata. Penyebab pasti dari Sindrom Stevens Johnson saat ini belum diketahui namun ditemukan beberapa hal yang memicu timbulnya Sindrom Stevens Johnson seperti obat-obatan atau infeksi virus. Mekanisme terjadinya sindroma pada Sindrom Stevens Johnson adalah reaksi hipersensitif terhadap zat yang memicunya. $^{2}$

Stevens Johnson Syndrome muncul biasanya tidak lama setelah obat disuntik atau diminum, dan besarnya kerusakan yang ditimbulkan kadang tidak berhubungan langsung dengan dosis, namun sangat ditentukan oleh reaksi tubuh pasien. Reaksi hipersensitif sangat sukar diramal, paling diketahui jika ada riwayat penyakit sebelumnya dan itu kadang tidak disadari pasien, jika tipe alergi tipe cepat yang seperti syok anafilaktik jika cepat ditangani pasien akan selamat dan tak bergejala sisa, namun jika Stevens Johnson Syndrome akan membutuhkan waktu pemulihan yang lama dan tidak segera menyebabkan kematian seperti syok anafilaktik. ${ }^{3}$

Oleh karena itu, beberapa kalangan disebut sebagai eritema multiforme mayor tetapi terjadi ketika setujuan dalam literatur. Sebagian besar penulis dan ahli berpendapat bahwa Stevens Johnson Syndrome dan nekrolisis epidermal toksik (NET) merupakan penyakit yang sama dengan manifestasi yang berbeda. Dengan alasan tersebut, banyak yang Jurnal Averrous Vol.5 No.1 Mei 2019 
menyebutkan Stevens Johnson Syndrome Nekrolisis Epidermal Toksik. Stevens Johnson Syndrome secara khas mengenai kulit dan membran mukosa. ${ }^{2}$

Di Indonesia sendiri tidak terdapat data pasti mengenai morbiditas terjadinya Stevens Johnson Syndrome. Namun, berdasarkan data oleh Djuanda beberapa obat yang sering menyebabkan SJS di Indonesia adalah obat golongan analgetik/antipiretik (45\%), karbamazepin (20\%), jamu (13.3\%) dan sisanya merupakan golongan obat lain seperti amoksisilin, kotrimoksasol, dilantin, klorokuin, dan seftriakson. ${ }^{4}$

\section{DEFINISI}

Stevens-Johnson syndrome (SJS) atau sindrom Stevens-Johnson dan toxic epidermal necrolysis (TEN) atau nekrolisis epidermal toksik adalah penyakit kulit yang disebabkan oleh alergi atau infeksi. Sindrom tersebut mengancam kondisi kulit yang mengakibatkan kematian sel-sel kulit sehingga epidermis mengelupas dan memisahkan dari dermis. Sindrom ini dianggap sebagai hipersensitivitas kompleks yang mempengaruhi kulit dan selaput lendir. Stevens Johnson Syndrome adalah sindroma yang mengenai kulit, selaput lendir orifisium dan mata dengan keadaan umum bervariasi dari ringan sampai berat. Kelainan pada kulit berupa eritema, vesikel, bula dapat disertai purpura. ${ }^{3}$

Stevens Johnson Syndrome adalah bentuk penyakit mukokutan dengan tanda dan gejala sistemik yang parah berupa lesi target dengan bentuk yang tidak teratur, disertai macula, vesikel, bula, dan purpura yang tersebar luas terutama pada rangka tubuh, terjadi pengelupasan epidermis kurang lebih sebesar 10\% dari area permukaan tubuh, serta melibatkan membran mukosa dari dua organ atau lebih. ${ }^{4}$

Sindrom Stevens Johnson umumnya terjadi pada anak-anak dan dewasa muda terutama pria. Tanda-tanda oral sindrom Stevens Johnson sama dengan eritema multiforme, perbedaannnya yaitu melibatkan kulit dan membran mukosa yang lebih luas, disertai gejala-gejala umum yang lebih parah, termasuk demam, malaise, sakit kepala, batuk, nyeri dada, diare, muntah dan artralgia. ${ }^{5}$ 


\section{EPIDEMIOLOGI}

Insiden SSJ dan NET jarang dijumpai. Keseluruhan insidensi SSJ dan NET diperkirakan 2 sampai 7 kasus per 1 juta orang per tahun. SSJ dan NET dapat terjadi pada semua usia tapi insidensinya bertambah di atas dekade ke-4 dan sering terjadi pada wanita, menunjukkan rasio jenis kelamin $0,6 .^{25,26}$ Penyakit infeksius juga dapat berdampak pada insidensi terjadinya TEN, yaitu pada pasien HIV dapat meningkat 100 kali lipat dibandingkan populasi umum, dengan jumlah hampir 1 kasus/seratus orang/tahun pada populasi HIV positif. Perbedaan regional pada peresepan obat, latar belakang genetik dari pasien (HLA, enzim metabolism), koeksistensi kanker, atau bersama dengan radioterapi dapat berdampak pada insidensi SSJ dan NET. Mortalitas penyakit tersebut $10 \%$ untuk SJS, 30\% untuk SJS / NET, dan lebih dari 30\% untuk NET. Dalam analisa kelangsungan hidup SJS / NET dengan angka mortalitas secara keseluruhan adalah 23\% pada enam minggu, $28 \%$ pada tiga bulan dan $34 \%$ pada satu tahun. Bertambahnya usia, komorbiditas yang signifikan, yang luasnya permukaan tubuh yang terlibat berkaitan dengan prognosis yang buruk. Di Amerika Serikat, evaluasi dari kematian menunjukkan resiko tujuh kali lebih tinggi pada orang kulit hitam dibandingkan dengan kulit putih. ${ }^{25,26,27,28,29}$

\section{ETIOLOGI}

Penyebab yang pasti belum diketahui, dikatakan multifaktorial. Ada yang beranggapan bahwa sindrom ini merupakan eritema multiforme yang berat dan disebut eritema multiforme mayor, sehinga dikatakan mempunyai penyebab yang sama. Beberapa faktor yang dapat menyebabkan timbulnya sindrom ini antara lain: ${ }^{4}$

1. Infeksi

a) Virus

Sindrom Stevens-Johnson dapat terjadi pada stadium permulaan dari infeksi saluran nafas atas oleh virus Pneumonia. Hal ini dapat terjadi pada Asian flu, Lympho Granuloma Venerium, Measles, Mumps dan vaksinasi Smalpox virus. Virus-virus Coxsackie, Echovirus dan Poliomyelits juga dapat menyebabkan Sindroma StevensJohnson.

\section{b) Bakteri}


Beberapa bakteri yang mungkin dapat menyebabkan Sindroma Stevens- Johnson ialah Brucelosis, Dyptheria, Erysipeloid, Glanders, Pneumonia, Psitacosis, Tuberculosis, Tularemia,Lepromatous Leprosy atau Typhoid Fever.

\section{c) Jamur}

Cocidiodomycosis dan Histoplasmosis dapat menyebabkan Eritema Multiforme

Bulosa, yang pada keadan berat juga dikatakan sebagai Sindroma Stevens-Johnson.

\section{d) Parasit}

Malaria dan Trichomoniasis juga dikatakan sebagai agen penyebab.

2. Alergi Sistemik terhadap:

\section{Obat}

Berbagai obat yang diduga dapat menyebabkan Sindrom Stevens-Johnson antara lain adalah penisilin dan derivatnya, streptomysin, sulfonamide, tetrasiklin, analgesik/antipiretik (misalnya deriva salisilat, pirazolon, metamizol, metampiron dan paracetamol), digitalis, hidralazin, barbiturat (Fenobarbital), kinin antipirin, chlorpromazin, karbamazepin dan jamu-jamuan.

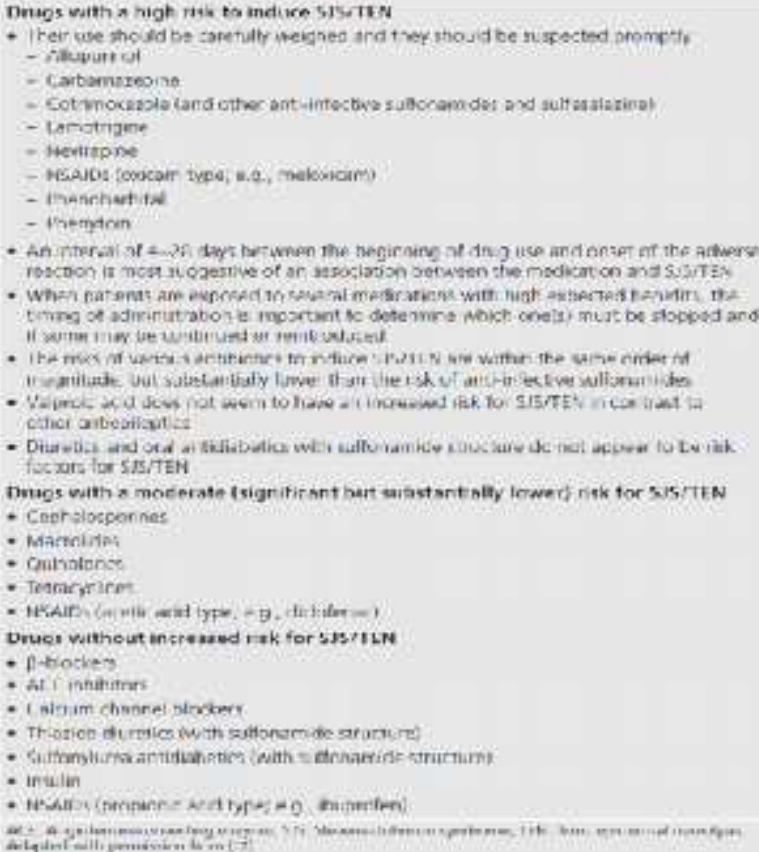

Gambar 2.1 Obat yang dapat menyebabkan SJS dan TEN ${ }^{30}$

3. Penyakit penyakit Kolagen Vaskuler. 
4. Pasca vaksinasi :

- BCG, Smalpox dan Poliomyelits.

5. Penyakit-penyakit keganasan :

- Karsinoma penyakit Hodgkins, limfoma, myeloma, dan polisitemia.

6. Kehamilan dan Menstruasi.

7. Neoplasma.

8. Radioterapi.

\section{KLASIFIKASI}

1. Sindrom Steven Johnson

- Surface area of epidermal detachment dibandingkan dengan detached dermis iaitu sebanyak $<10 \%{ }^{3}$

2. Sindron Steven Johnson dan TEN

- Surface area of epidermal detachment dibandingkan dengan detached dermis iaitu sebanyak $<10-30 \%{ }^{3}$

3. TEN

- Surface area of epidermal detachment dibandingkan dengan detached dermis iaitu sebanyak $>30 \%{ }^{3}$

\section{PATOFISIOLOGI}

Stevens Johnson Syndrome merupakan kelainan hipersensitivitas yang dimediasi kompleks imun yang disebabkan oleh obat-obatan, infeksi virus dan keganasan. Patogenesisnya belum jelas, disangka disebabkan oleh reaksi hipersensitif tipe III dan IV. ${ }^{1}$

Reaksi hipersensitif tipe III terjadi akibat terbentuknya komplek antigen antibodi yang mikro presitipasi sehingga terjadi aktifitas sistem komplemen. Akibatnya terjadi akumulasi neutrofil yang kemudian melepaskan enzim dan menyebab kerusakan jaringan pada organ sasaran (target organ). Hal ini terjadi sewaktu komplek antigen antibodi yang bersirkulasi dalam darah mengendap di dalam pembuluh darah atau jaringan. ${ }^{2}$

Antibiotik tidak ditujukan kepada jaringan tersebut, tetapi terperangkap dalam jaringan kapilernya. Pada beberapa kasus antigen asing dapat melekat ke jaringan menyebabkan terbentuknya komplek antigen antibodi ditempat tersebut. Reaksi tipe ini Jurnal Averrous Vol.5 No.1 Mei 2019 
mengaktifkan komplemen dan degranulasi sel mast sehingga terjadi kerusakan jaringan atau kapiler ditempat terjadinya reaksi tersebut. Neutrofil tertarik ke daerah tersebut dan mulai memtagositosis sel-sel yang rusak sehingga terjadi pelepasan enzim-enzim sel, serta penimbunan sisa sel. Hal ini menyebabkan siklus peradangan berlanjut. ${ }^{1}$

Reaksi hipersensitifitas tipe IV terjadi akibat limfosit $\mathrm{T}$ yang tersintesisasi berkontak kembali dengan antigen yang sama kemudian limtokin dilepaskan sebagai reaksi radang. Pada reaksi ini diperantarai oleh sel T, terjadi pengaktifan sel T. Penghasil limfokin atau sitotoksik atau suatu antigen sehingga terjadi penghancuran sel-sel yang bersangkutan. Reaksi yang diperantarai oleh sel ini bersifat lambat (delayed) memerlukan waktu 14 jam sampai 27 jam untuk terbentuknya. ${ }^{5}$

Pada beberapa kasus yang dilakukan biopsi kulit dapat ditemukan endapan IgM, IgA, C3, dan fibrin, serta kompleks imun beredar dalam sirkulasi. Antigen penyebab berupa hapten akan berikatan dengan karier yang dapat merangsang respons imun spesifik sehingga terbentuk kompleks imun beredar. Hapten atau karier tersebut dapat berupa faktor penyebab (misalnya virus, partikel obat atau metabolitnya) atau produk yang timbul akibat aktivitas faktor penyebab tersebut (struktur sel atau jaringan sel yang rusak dan terbebas akibat infeksi, inflamasi, atau proses metabolik).

Kompleks imun beredar dapat mengendap di daerah kulit dan mukosa, serta menimbulkan kerusakan jaringan akibat aktivasi komplemen dan reaksi inflamasi yang terjadi. Kerusakan jaringan dapat pula terjadi akibat aktivitas sel $\mathrm{T}$ serta mediator yang dihasilkannya. Kerusakan jaringan yang terlihat sebagai kelainan klinis lokal di kulit dan mukosa dapat pula disertai gejala sistemik akibat aktivitas mediator serta produk inflamasi lainnya. Adanya reaksi imun sitotoksik juga mengakibatkan apoptosis keratinosit yang akhirnya menyebabkan kerusakan epidermis. ${ }^{15}$

Oleh karena proses hipersensitivitas, maka terjadi kerusakan kulit sehingga terjadi seperti kegagalan fungsi kulit yang menyebabkan kehilangan cairan, stress hormonal diikuti peningkatan resistensi terhadap insulin, hiperglikemia dan glukosuria, kegagalan termoregulasi, kegagalan fungsi imun, dan infeksi. ${ }^{16}$ 


\section{MANIFESTASI KLINIS}

Gejala awal dari toxic epidermal necrolysis (TEN) dan Stevens-Johnson Syndrome (SJS) mungkin tidak spesifik dan termasuk gejala seperti demam, mata menyengat dan ketidaknyamanan setelah menelan. Biasanya, gejala-gejala ini mendahului manifestasi kulit oleh beberapa hari. Lokasi awal keterlibatan kulit adalah wilayah presternal dari batang dan wajah, tetapi juga telapak tangan dan kaki. Keterlibatan (eritema dan erosi) dari bukal, alat kelamin dan / atau mukosa mata terjadi pada lebih dari 90\% dari pasien, dan dalam beberapa kasus sistem pernapasan dan pencernaan juga dipengaruhi. ${ }^{6}$

Keterlibatan okular akibat timbulnya penyakit sering terjadi, dan dapat berkisar dari akut konjungtivitis, edema kelopak mata, eritema, krusta, dan okular debit, ke membran konjungtiva atau pseduomembrane pembentukan atau erosi kornea, dan, pada kasus yang berat, untuk cicatrizing lesi, symblepharon, forniks foreshortening, dan ulserasi kornea. ${ }^{7}$

Pada fase kedua, sebagian besar kawasan pelepasan epidermal berkembang. Dengan tidak adanya pelepasan epidermal, pemeriksaan kulit yang lebih rinci harus dilakukan oleh mengerahkan tekanan mekanik tangensial pada beberapa zona eritematosa (Nikolsky sign).

Tabel 2.1 klinis yang membedakan SJS, SJS-TEN , dan TEN. ${ }^{6}$

\begin{tabular}{|c|c|c|c|}
\hline $\begin{array}{l}\text { Entitas } \\
\text { klinis }\end{array}$ & SJS & SJS-TEN & TEN \\
\hline primer & 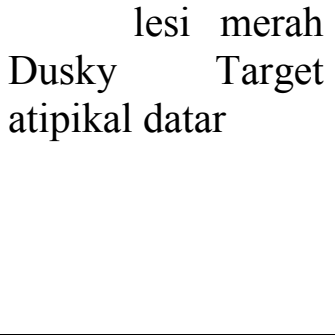 & 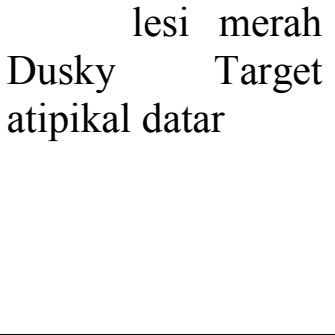 & 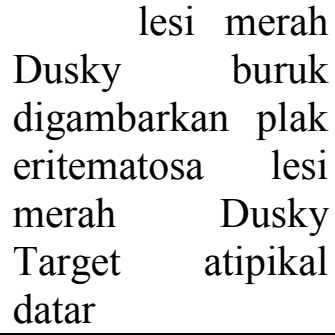 \\
\hline Distribusi & \begin{tabular}{ll} 
& \multicolumn{2}{c}{ Terisolasi } \\
lesi & \\
Pertemuan & $(+)$ \\
pada wajah dan \\
bagasi
\end{tabular} & \begin{tabular}{l}
\multicolumn{2}{c}{ lesi } \\
terisolasi \\
Pertemuan \\
$(++)$ pada wajah \\
dan \\
bagasi
\end{tabular} & $\begin{array}{l}\text { lesi } \\
\text { terisolasi (jarang) } \\
\text { Pertemuan } \\
(+++) \text { pada wajah, } \\
\text { batang, dan } \\
\text { di tempat lain }\end{array}$ \\
\hline $\begin{array}{l}\text { Keterlibata } \\
\text { n mukosa }\end{array}$ & $\mathrm{Ya}$ & $\mathrm{Ya}$ & $\mathrm{Ya}$ \\
\hline $\begin{array}{l}\text { Gejala } \\
\text { sistemik }\end{array}$ & Biasanya & Selalu & Selalu \\
\hline
\end{tabular}

Jurnal Averrous Vol.5 No.1 Mei 2019 


\begin{tabular}{|l|l|l|l|}
\hline $\begin{array}{l}\text { Detasemen } \\
\text { (permukaan } \\
\text { tubuh\% } \\
\text { luas area) }\end{array}$ & $<10$ & $10-30$ & $>30$ \\
\hline
\end{tabular}

Adapun 3 kelainan utama yang muncul pada SJS, antara lain:

\section{a. Kelainan pada kulit}

Kelainan yang dapat terjadi pada kulit penderita sindrom Stevens-Johnson, antara lain timbulnya ruam yang berkembang menjadi eritema, papula, vesikel, dan bula. Sedangkan tanda patognomonik yang muncul adalah adanya lesi target atau targetoid lesions. ${ }^{17}$

Berbeda dengan lesi target pada eritema multiforme, lesi target pada sindrom Stevens-Johnson merupakan lesi atipikal datar yang hanya memiliki 2 zona warna dengan batasan yang buruk. Selain itu, makula purpura yang banyak dan luas juga ditemukan pada bagian tubuh penderita sindrom Stevens-Johnson. ${ }^{18}$ Lesi yang muncul dapat pecah dan meninggalkan kulit yang terbuka. Hal tersebut menyebabkan tubuh rentan terhadap infeksi sekunder. ${ }^{19}$

Pengelupasan kulit umum terjadi pada sindrom ini, ditandai dengan tanda Nikolsky positif. Pengelupasan paling banyak terjadi pada area tubuh yang tertekan seperti pada bagian punggung dan bokong. Apabila pengelupasan menyebar kurang dari 10\% area tubuh, maka termasuk sindrom Stevens-Johnson. Jika 10-30\% disebut Stevens Johnson Syndrome - Toxic Epidermal Necrolysis (SJS-TEN). Serta jika lebih dari 30\% area tubuh, maka disebut Toxic Epidermal Necrolysis (TEN). ${ }^{20,21}$

\section{b. Kelainan pada mukosa}

Kelainan pada mukosa sebagian besar melibatkan mukosa mulut dan esofageal, namun dapat pula melibatkan mukosa pada paru-paru dan bagian genital. ${ }^{27}$ Adanya kelainan pada mukosa dapat menyebabkan eritema, edema, pengelupasan, pelepuhan, ulserasi, dan nekrosis. ${ }^{19}$

Pada mukosa mulut, kelainan dapat berupa stomatitis pada bibir, lidah, dan mukosa bukal mulut. Stomatitis tersebut diperparah dengan timbulnya bula yang dapat pecah sewaktu-waktu. Bula yang pecah dapat menimbulkan krusta atau kerak kehitaman terutama 
pada bibir penderita. ${ }^{1}$ Selain itu, lesi juga dapat timbul pada mukosa orofaring, percabangan bronkitrakeal, dan esofagus, sehingga menyebabkan penderita sulit untuk bernapas dan mencerna makanan. Serta pada saluran genitalurinaria sehingga menyulitkan proses mikturia atau buang air kecil. ${ }^{21}$

\section{c. Kelainan pada mata}

Kelainan pada mata yang terjadi dapat berupa hiperemia konjungtiva. Kelopak mata dapat melekat dan apabila dipaksakan untuk lepas, maka dapat merobek epidermis. Erosi pseudomembran pada konjungtiva juga dapat menyebabkan sinekia atau pelekatan antara konjungtiva dan kelopak mata. Seringkali dapat pula terjadi peradangan atau keratitis pada kornea mata. ${ }^{19,27}$

\section{DIAGNOSIS BANDING}

Diagnosis diferensial utama dari SJS / TEN adalah penyakit autoimun blistering, termasuk linear IgA dermatosis dan pemfigus paraneoplastic tetapi juga vulgaris pemfigus dan pemfigoid bulosa, exanthematous umum akut pustulosis (AGEP), disebarluaskan obat bulosa tetap erupsi dan scalded skin syndrome staphyloccocal (SSSS). SSSS adalah salah diferensial yang paling penting diagnosa di masa lalu, tapi kejadian yang saat ini sangat rendah dengan 0,09 dan 0,13 kasus per satu juta penduduk per tahun. ${ }^{8}$

1. Eritema multiformis (EM)

Bagian tubuh yang terkena EM ialah kulit dan kadang-kadang selaput lendir. Penyebabnya belum diketahui secara pasti. Yang dapat membedakan EM dengan SJS ialah luas permukaan tubuh yang terkena. Pada EM ialah $<10 \%$ sedangkan pada SJS ialag $>30 \%$.

2. Nekrolisis Epidermal Toksik (NET)

Penyakit ini sangat mirip dengan Sindrom Stevens- Johnson. $\square$ Pada NET terdapı Epidemolisis (Epidermis terlepas dari dasarnya) yang menyeluruh dan keadaan umum penderita biasanya lebih buruk/berat.

3. Eritroderma dan erupsi obat eritematosa

Eritema makulopapular yang umum dan simetris dari erupsi obat dapat meniru awal SJS/NET. Namun, pada erupsi obat eritematosa keterlibatan mukosa kurang tapi nyeri kulit pada TEN menonjol. 


\section{Erupsi Pustural Obat}

Reaksi obat pustular, termasuk acute generalized exanthematous pustulosis (AGEP), juga bisa menjadi berat dan mirip dengan gejala awal SJS/NET. AGEP merupakan erupsi yang terdiri dari non-follicularly centered pustules yang sering dimulai di leher dan daerah intertriginosa.

\section{Erupsi Fototoksik}

Erupsi fototoksik disebabkan oleh interaksi langsung bahan kimia dengan sinar matahari yang dapat menjadi racun untuk kulit. Reaksi fototoksik paling umum yang dibingungkan dengan SJS/NET adalah reaksi fototoksik yang terjadi akibat pemakaian oral. Sebagai contoh, fluoroquinolones dapat menghasilkan reaksi fototoksik, yang dapat menyebabkan pengelupasan epidermis luas.

6. Toxic shock syndrome

Toxic shock syndrome (TSS) yang klasik disebabkan oleh Staphylococcus aureus, meskipun gangguan yang sama dapat disebabkan oleh racun rantai elaborasi dari Grup A streptokokus. Dibandingkan dengan SJS/NET, TSS hadiah dengan keterlibatan lebih menonjol dari beberapa sistem organ.

\section{Staphylococcal scalded skin syndrome}

SSSS dibedakan secara klinis dari SJS/NET terutama oleh epidemiologi dan dari selaput lendir. Diagnosis didukung oleh pemeriksaan histologis, yang mengungkapkan peluruhan hanya lapisan atas epidermis. ${ }^{23}$

\section{DIAGNOSIS}

Semua kasus dugaan SJS dan TEN harus dikonfirmasi oleh biopsi kulit untuk histologis dan pemeriksaan imunofluoresensi. Awal menunjukkan lesi lapisan suprabasal keratinosit apoptosis. kemudian lesi menunjukkan ketebalan penuh epidermal nekrosis dan pemisahan dari epidermis dari dermis. Sejak 90\% SJS keterlibatan membran mukus tidak adanya tersebut harus meminta seseorang untuk mempertimbangkan alternatif diagnosis. ${ }^{8}$ Sejumlah kondisi penting duga SJS karenanya bukti histologis penting:

1. Erythema multiforme major 
2. Staphylococcal scalded skin syndrome

3. Purpura fulminant

4. Disseminated intravascular coagulation with skin necrosis

5. Acute generalised exanthematous pustulosis

6. Generalised bullous fixed drug eruption

7. Chemical toxicity (methotrexate, colchicines etc)

8. Burns

9. Graft-versus-host disease

10. Pemphigus

Tidak ada pemeriksaan laboratorium yang spesifik kecuali biopsi yang dapat menegakkan diagnose SSJ. Pada pemeriksaan darah lengkap dapat menunjukkan anemia, limfopenia dan jumlah leukosit yang normal atau leukositosis nonspesifik, eosinophilia jarang dan neutropenia dapat terjadi pada $1 / 3$ pasien. Peningkatan leukositosis yang berat mengindikasikan adanya infeksi bakteri yang lainnya. Kultur darah dan kulit sangat dianjurkan karena adanya insidensi infeksi bakteri yang serius dan sepsis yang berhubungan dengan morbiditas dan mortalitas. ${ }^{26,31}$

Evaluasi terhadap frekuensi pernafasan dan oksigenasi darah adalah langkah pertama untuk dilakukan di Instalasi Gawat Darurat (IGD). Segala perubahan harus diperiksa secara menyeluruh melalui pengukuran level gas darah arteri. Tingkat serum bikarbonat dibawah $20 \mu \mathrm{m}$ mengindikasikan prognosis yang buruk. Pada umumnya disebabkan oleh alkalosis pernafasan yang terkait dengan keterlibatan spesifik bronkus serta sedikit pengaruh asidosis metabolik. 25

Kelainan hasil pemeriksaan laboratorium yang ditemukan pada SSJ/NET adalah gangguan keseimbangan elektrolit, hipoalbuminemia, hipoproteinemia, insufisiensi ginjal, azotemia. prerenal, leukositosis ringan, anemia, neutropenia, sedikit peningkatan enzim hepar dan amilase, hiperglikemia. Serum urea nitrogen $>10 \mathrm{mmol} / \mathrm{L}$ dan glukosa $>14 \mathrm{mmol} / \mathrm{L}$ dianggap penanda keparahan penyakit. ${ }^{25,26}$

Seluruh kasus yang disangkakan SSJ dan NET harus dikonfirmasi melalui pemeriksaan biopsi kulit untuk histopatologi dan pemeriksaan immunofluoresence. Lesi awal menunjukkan apoptosis keratinosit pada lapisan suprabasal. Lesi akhirnya akan Jurnal Averrous Vol.5 No.1 Mei 2019 
memperlihatkan nekrosis epidermal yang tebal dan pelepasan epidermis dari dermis. Infiltrasi sel mononuclear dengan kepadatan sedang pada papilla dermis dapat terlihat, sebagian besar diwakili oleh limfosit dan makrofag. ${ }^{26,32,33}$

\section{PENATALAKSANAAN}

Manajemen pasien harus dikerjakan dengan cepat dan tepat. Hal penting yang harus dilakukan mendiagnosis dengan cepat, perawatan khusus dan multidisiplin tim pada intensive care unit (ICU) atau unit luka bakar. Perawatan suportif termasuk menjaga keseimbangan hemodinamik dan mencegah komplikasi yang mengancam jiwa. Tujuan pada dasarnya sama dengan tujuan luka bakar yang luas. ${ }^{22,27}$

\section{Penatalaksanaan Umum}

Adapun prinsip - prinsip utama perawatan suportif adalah sama seperti pada luka bakar . Selain menghentikan pemberian obat penyebab, dilakukan perawatan luka, manajemen cairan dan elektrolit, dukungan nutrisi, perawatan mata, manajemen suhu, kontrol nyeri dan pemantauan pengobatan infeksi. ${ }^{34}$

\section{A. Penghentian Obat Penyebab}

Diagnosis dini dengan pengenalan dini dan penghentian segera dari segala obat-obatan yang diduga menjadi penyebab sangat menentukan hasil akhir. Morbiditas dan mortalitas meningkat jika obat-obatan yang menjadi penyebab terlambat dihentikan. Ignacio Garcia dkk melakukan penelitian untuk menentukan apakah waktu penghentian obat berhubungan dengan prognosis pasien NET atau SSJ. Hasil penelitian menunujukkan bahwa angka kematian lebih rendah apabila obat penyebab dengan waktu paruh eliminasi yang pendek dihentikan tidak lebih dari 1 hari ketika bula atau erosi muncul. Pasien yang mengkonsumsi obat penyebab dengan waktu paruh yang panjang, memiliki resiko kematian yang lebih tinggi. ${ }^{22}$

\section{B. Menjaga Keseimbangan Cairan, Termoregulasi dan Nutrisi}

SSJ/NET dihubungkan dengan hilangnya cairan yang signifikan dikarenakan erosi, yang menyebabkan hipovolemia dan ketidakseimbangan elektrolit. Penggantian ulang cairan harus dimulai secepat mungkin dan disesuaikan setiap harinya. Jumlah infus Jurnal Averrous Vol.5 No.1 Mei 2019 
biasanya kurang dari luka bakar pada tingkat keparahan yang sama, karena interstisial edema tidak dijumpai. Aliran vena perifer lebih disukai jika dimungkinkan, karena bagian tempat masuk aliran sentral sering melibatkan pelepasan epidermis dan mudah terinfeksi. Hal lain yang perlu dijaga adalah temperatur lingkungan, sebaiknya dinaikkan hingga $28^{\circ} \mathrm{C}$ hingga $30^{\circ} \mathrm{C}-32^{\circ} \mathrm{C}$ untuk mencegah pengeluaran kalori yang berlebihan karena kehilangan epidermis. Penggunaan pelembab udara saat tidur meningkatan rasa nyaman pasien. ${ }^{25,34}$

Pasien SSJ dan NET mengalami status katabolik yang tinggi sehingga memerlukan tambahan nutrisi. Kebutuhan energi dan protein berhubungan dengan luas area tubuh yang terlibat. Terapi enteral lebih diutamakan daripada parenteral karena dapat ditoleransi dengan lebih baik dan dapat memberikan pemasukan kalori lebih banyak. Sedangkan terapi parenteral membutuhkan akses vena sentral dan meningkatkan resiko sepsis. Dapat juga digunakan nasogastric tube apabila terdapat lesi mukosa mulut. ${ }^{25}$

C. Antibiotik

Antibiotik profilaksis bukan merupakan indikasi, malah mungkin dapat menyebabkan resistensi organisme dan meningkatnya mortalitas. Pasien diberikan antibiotik apabila terdapat tanda-tanda klinis infeksi. Tanda-tanda tersebut antara lain perubahan status mental, mengigil, hipoterimia, menurunnya pengeluaran urin dan penurunan kondisi klinis. Selain itu juga terdapat peningkatan bakteri pada kultur kulit. Kultur rutin dari kulit, darah, urin, dan kanula intravascular sangat disarankan. Penyebab utama dari sepsis pada pasien SSJ/NET adalah Staphylococus aureus dan Pseudomonas aeruginosa. Spesies Staphylococus yang dikultur dari darah biasanya sama dengan yang dikultur dari kulit. ${ }^{28,32,34}$

\section{Perawatan Luka}

Pembersihan luka (debridement) nekrosis epidermis yang ekstensif dan agresif tidak direkomendasikan pada kasus NE karena nekrosis permukaan bukanlah halangan untuk reepitelisasi, dan justru dapat mempercepat proliferasi sel-sel stem berkenaan dengan sitokin peradangan. ${ }^{25}$

Pengobatan topikal diberikan untuk mengurangi kehilangan cairan, elektrolit, dan mencegah terjadinya infeksi. Debridement dilakukan dengan pemberian analgetik dengan derivat morfin sebelumnya. Kulit dibersihkan dengan antiseptic yang ringan dan solusio Jurnal Averrous Vol.5 No.1 Mei 2019 
antibiotik seperti sabun povidone iodine, chlorhexidine, silver nitrate untuk mengurangi pertumbuhan bakteri. $^{25,34}$

\section{E. Perawatan Mata dan Mulut}

Komplikasi oftalmik adalah satu dari permasalahan tersering terhadap SSJ/NET. Sekitar $80 \%$ pasien yang dihospitalisasi mengalami komplikasi ocular akut yang sama pada SSJ maupun NET dengan keterlibatan berat sebesar 25\%. Gejala sisa kronis terjadi pada sekitar 35\% pasien, biasanya disebabkan oleh skar konjungtiva. Permasalahan residual pada mata yang paling sering dilaporkan adalah fotosensitivitas kronis dan mata kering. Namun pada beberapa pasien penyakit ocular kronis bermanifestasi sebagai kegagalan permukaan mata, inflamasi episodik rekuren, skleritis, atau sikatriks konjungtiva progresif yang menyerupai pemfigoid membran mukosa. Perawatan mata meliputi pembersihan kelopak mata dan memberi pelumas setiap hari dengan obat tetes atau salep mata. ${ }^{22,34}$

Mulut harus dibersihkan beberapa kali dalam sehari untuk menjaga kebersihan rongga mulut, berulang-ulang kumur-kumur dengan antiseptik dan mengoleskan topikal anestesi seperti xylocaine, lignocaine sebelum makan sehingga dapat mengurangi sakit waktu menelan. Tindakan ini hanya direkomendasikan bila penderita tidak mengalami pharyngealdysphagia. Hindari makanan yang terlalu panas atau dingin, makanan yang asam dan kasar. Sebaiknya makanan yang halus dan basah sehingga tidak mengiritasi lesi pada mulut. Kadang-kadang diberikan obat anti fungal seperti mikostatin, obat kumur-kumur soda bikarbonat, hydrogen peroksida dengan konsentrasi ringan. Pemberian topikal pada bibir seperti vaselin, lanolin. ${ }^{28}$

\section{F. Perawatan vulvovaginal}

Pencegahan pada vulvovaginal dengan memeriksakan ginekologi dini harus dilakukan pada semua pasien wanita penderita SJS/NET. Tujuan dari pengobatan ini untuk mencegah keterlibatan vagina yang membentuk adhesi dan aglutinasi labial serta mencegah adenosis vagina ( bila dijumpai keterlibatan metaplastik serviks / endometrium, epitel kelenjar divulva atau vagina ). Pencegahan dengan memberikan kortikosteroid intravaginal diterapkan dua kali sehari pada pasien dengan lesi ulseratif sampai resolusi fase akut penyakit. Pemberian kortikosteroid topical ini disertai dengan krim antijamur topical untuk mencegah kandidiasis vagina. ${ }^{34}$ 


\section{Penatalaksanaan Spesifik}

\section{A. Kortikosteroid Sistemik}

Pemakaian kortikosteroid sistemik masih kontroversial. Beberapa studi menemukan bahwa pemberian kortikosteroid dapat mencegah perluasan penyakit bila diberikan pada fase awal. Studi lain menyebutkan bahwa steroid tidak menghentikan perkembangan penyakit dan bahkan dihubungkan dengan kenaikan mortalitas dan efek samping, khususnya sepsis. Selanjutnya, banyak kasus telah dilaporkan yang telah diobati dengan kortikosteroid, akan meningkatkan resiko SSJ/NET. Jadi, kortikosteroid sistemik tidak dapat direkomendasikan sebagai pedoman utama pengobatan SSJ/NET.

Kortikosteroid dapat diberikan dalam 72 jam pertama setelah onset untuk mencegah penyebaran yang lebih luas, dapat diberikan selama 3-5 hari diikuti penurunan secara bertahap (tapering off). Dosis yang dapat diberikan adalah 30-40 mg sehari. Dapat digunakan deksametason secara intravena dengan dosis permulaan 4-6 x $5 \mathrm{mg}$ sehari. Tapering off hendaknya cepat dilakukan karena pada umumnya penyebab SSJ/NET adalah eksogen (alergi). Pada SSJ/NET, kortikosteroid berperan sebagai anti inflamasi, imunosupresif dan anti apoptosis. Kortikosteroid juga mempunyai efek anti-apoptosis pada banyak jaringan termasuk kulit dengan menghambat aktivitas Fas-FasL. ${ }^{28,35,36,34}$

\section{B. Immunoglobulin Intravena (IVIG)}

Anjuran pemakaian immunoglobulin intravena dosis tinggi didasarkan pada demonstrasi bahwa kematian sel yang diperantarai Fas dapat dibatalkan oleh aktivitas antiFas yang ada dalam sejumlah immunoglobulin manusia normal. Keuntungan telah ditegaskan oleh beberapa studi dan laporan kasus tetapi disangkal oleh beberapa yang lainnya. $^{33,34}$

IVIG mengandung antibodi imun yang mengganggu jalur apoptosis yang diperantarai oleh FasL dan reseptor. Secara teoritis, yang paling baik pemberian IVIG pada awal (24-72 jam setelah munculnya bulla pertama), sebelum Fas-L dan reseptor berikatan, walaupun masih efektif jika bulla yang baru muncul. Pasien dengan defisiensi Ig A akan terjadi anafilaksis akibat IVIG. Sangat baik dilakukan pemeriksaan tingkat IgA sebelum pemberian namun menunggu hasilnya dapat menyebabkan keterlambatan pengobatan. Jurnal Averrous Vol.5 No.1 Mei 2019 
Hasil studi dari IVIG pada SSJ dan NET masih diperdebatkan, dan IVIG tidak disarankan sebagai pengobatan rutin. Namun jika diputuskan untuk menggunakan IVIG dengan penyakit berat diberikan dosis $1 \mathrm{gr} / \mathrm{kgBB}$ perhari selama 3 hari berturut - turut ) pada fase awal penyakit yaitu dalam waktu 24-48 jam dari onset gejala.13,15 Efek samping IVIG termasuk ginjal, hematologi dan komplikasi trombotik. Resiko komplikasi yang serius meningkat pada pasien usia tua yang menerima dosis tinggi IVIG serta pada penderita gangguan ginjal dan jantung. Telah dilaporkan hemolysis berat dan nefropati pada pasien SJS/NET yang diobati dengan IVIG. ${ }^{34}$

\section{Siklosporin A}

Siklosporin merupakan suatu agen imunosupresif yang penuh kekuatan dihubungkan dengan efek biologik yang secara teoritis berguna dalam pengobatan SSJ/NET. Dalam sebuah serial kasus retrospektif, 11 pasien NET diterapi dengan siklosporin A (3 mg/kg/hari), terapi siklosporin A menyebabkan reepitelisasi yang cepat dan angka mortalitas yang rendah bila dibandingkan dengan siklofosfamid dan kortikosteroid ( $0 \%$ vs 50\%). Berbagai laporan kasus individual yang menggunakan dosis 3 hingga $5 \mathrm{mg} / \mathrm{kg} /$ hari secara intravena atau oral juga telah dipublikasikan memperlambat perkembangan SJS/NET tanpa toksisitas yang signifikan. Durasi pengobatan bervariasi mulai dari 8 hingga 24 hari, biasanya hingga pasien mengalami reepitelisasi. Efek samping termasuk peningkatan ringan dari serum kreatinin, hipertensi dan infeksi. Siklofosfamid sebagai bahan tunggal telah digunakan meskipun saat ini tidak digunakan di kebanyakan sentra. $^{22,34}$

D. Agen TNF- $\alpha$

Dalam beberapa laporan kasus dengan pemberian infus tunggal $5 \mathrm{mg} / \mathrm{kgbb} \mathrm{TNF}-\alpha$ menghentikan perluasan dan perkembangan dari SJS/NET dan memicu epitelisasi. Pemberian etanercept $50 \mathrm{mg}$ inj subkutan telah berhasil digunakan dalam sejumlah kecil pasien. $^{34}$

\section{E. Plasmafaresis atau Hemodialisis}

Dasar pemikiran untuk memakai plasmafaresis atau hemodialisis adalah mendorong perpindahan obat yang salah, metabolitnya, atau mediator peradangan seperti sitokin. Sebuah laporan kasus kecil melaporkan efikasi dan keamanannya dalam penatalaksanaan Jurnal Averrous Vol.5 No.1 Mei 2019 
SSJ/NET. Bagaimanapun, mempertimbangkan tidak adanya dasar dan adanya resiko yang dihubungkan dengan pemasangan kateter intravaskular, penatalaksanaan ini tidak direkomendasikan. ${ }^{34}$

\section{KOMPLIKASI}

Komplikasi yang tersering ialah Bronchopneumonia (16\%) yang dapat menyebabkan kematian. Komplikasi yang lain ialah kehilangan cairan atau darah ,gangguan keseimbangan elektrolit sehingga dapat menyebabkan shock .Pada mata dapat terjadi kebutaan karena gangguan Lakrimasi. ${ }^{14}$

\section{PROGNOSIS}

Dengan penanganan yang tepat dan cepat maka prognosis Sindrom Stevens-Johnson sangat baik. Dalam ke pustaka anangka kematian berkisar antara 5-15 \%. Dibagian kulit dan kelamin RS Cipto mangunkusumo angka kematian hanya sekitar 3,5\%. Kematian biasanya terjadi akibat sekunder infeksi. ${ }^{14}$

Indikator dan perkiraan mortalitas disajikan dalam gambar berikut:

SCORTEN variables

1. Extent of epidermal detachment $>10 \%$

2. Age $>40 \mathrm{yr}$

3. Heart rate $>120 / \mathrm{min}$

4. Bicarbonate $<20 \mathrm{mmol} / 1$

5. Serum urea nitrogen $>28 \mathrm{mg} / \mathrm{dl}$

6 . Glucose $>252 \mathrm{mg} / \mathrm{dl}$

7. History of malignancy

Gambar 2.2 SCORTEN scoring system ${ }^{24}$ 
Gambar 2.3 Perkiraan mortalitas berdasarkan skor total SCORTEN ${ }^{24}$

\section{REFERENSI}

1. Adithan C. Stevens-Johnson Syndrome. In: Drug Alert. JIPMER. 2006;2(1). India.

2. Djuanda A. Sindrom Stevens-Johnson. Ilmu Penyakit Kulit dan Kelamin edisi 5. Bagian Ilmu Penyakit Kulit dan Kelamin Fakultas Kedokteran Universitas Indonesia. Balai Penerbit Fakultas Kedokteran Universitas Indonesia. Jakarta. 2007:163-5.

3. Djuanda A.:"Sindroma Stevens-Johnson",MDK,vol.9 no.4, Mei 190, halaman 50.

4. V.K Sharma GGS. Adverse cutaneous reaction to drugs; an overview. J Postgard Med. 1996;42((1))

5. A Mansjoer S, Wardhani WI, Setiowulan W. Erupsi Alergi Obat.. Kapita Selekta Kedokteran Edisi ketiga Jilid 2. Jakarta: Fakultas Kedokteran Universitas Indonesia. Media Aesculapius; 2000.

6. Lebargy F, Wolkenstein P, Gisselbrecht M, Lange F, Fleury-Feith J, Delclaux C, Roupie E, Revuz J, Roujeau JC: Pulmonary complications in toxic epidermal necrolysis: a prospective clinical study. Intensive Care Med 1997, 23:1237-1244.

7. Chang YS, Huang FC, Tseng SH, Hsu CK, Ho CL, Sheu HM: Erythema multiforme, Stevens-Johnson syndrome, and toxic epidermal necrolysis: acute ocular manifestations, causes, and management. Cornea 2007, 26:123-129.

8. Mockenhaupt M, Messenheimer J, Tennis P, Schlingmann J: Risk of Stevens-Johnson syndrome and toxic epidermal necrolysis in new users of antiepileptics. Neurology 2005, 64:1134-1138.)

9. Roujeau, JC, Chosidow, O, Saiag, P, Guillaume, JC. Toxic epidermal necrolysis (Lyell syndrome). J Am Acad Dermatol 1990; 23:1039

10. Westly, ED, Wechsler, HL. Toxic epidermal necrolysis. Granulocytic leukopenia as a prognostic indicator. Arch Dermatol 1984; 120:721

11. R.P Langlais CSM. Colour Atlas of Common Oral Diseases. Philadelpia: Lea \&Febiger; 2003

12. Siregar RS.Sindrom Stevens Johnson. Saripati Penyakit Kulit 2nd edition. Jakarta: EGC; 2004.p. 141-2.

13. Adithan C. Stevens-Johnson Syndrome. In: Drug Alert. JIPMER. 2006;2(1). India 
14. A Mansjoer S, Wardhani WI, Setiowulan W. Erupsi Alergi Obat. .Kapita Selekta Kedokteran Edisi ketiga Jilid 2. Jakarta: Fakultas Kedokteran Universitas Indonesia. Media Aesculapius; 2000.

15. NN. Sindrom Steven-Johnson, manifestasi klinis, dan penanganannya. Didapat dari: http://allergycliniconline.com.

16. Majiid Sumardi. Steven Johnsons Syndrome.

17. Monica. Sindrom Stevens-Johnson. Didapat dari: http://elib.fk.uwks.ac.id/.

18. Mockenhaupt M. The current understanding of Stevens-Johnson syndrome and toxic epidermal necrolysis. Expert Review Clinical Immunology. 2011;7(6):803-15.

19. Foster CS. Stevens-Johnson syndrome. Medscape. 2013. Didapat dari: http://emedicine.medscape.com/.

20. Mockenhaupt M. The current understanding of Stevens-Johnson syndrome and toxic epidermal necrolysis. Expert Review Clinical Immunology. 2011;7(6):803-15.

21. Klein PA. Dermatologic manifestation of Stevens-Johnson syndrome and toxic epidermal necrolysis. Medscape. 2013. Didapat dari: http://emedicine.medscape.com/.

22. Knowles S, Shear NH. Clinical risk management of stevens Johnson syndrome, toxic epidermal necrolysis. Dalam: Spectrum; 2009;22:441-451

23. Nirken, M. H. dan High, W. A. Stevens-Johnson syndrome and toxic epidermal necrolysis: Clinical manifestations; pathogenesis; and diagnosis. Didapat dari http://nihlibrary.ors.nih.gov/.

24. Abood Gerard J., Nickoloff Brian J., Gamelli Richard L. 2008. 'Treatment Strategies in Toxic Epidermal Necrolysis Syndrome: Where Are We At?' Journal of Burn Care and Research Volume 29, Number1, January/February 2008, American Burn Association. p. 272.

25. Valeyrie Allanore L, Roujeau JC. Epidermal Necrolysis (Steven Johnsosns Syndrome and Toxic Epidermal Necrolysis). Dalam: Wolff K, Goldsmith LA, Katz SI, Gilchrest BA, Paller AS, Leffel DJ, editors. Fitzpatricks Dermatology in General Medicine. 7th ed. New York: Mc Graw;2008;349-55

26. Milton H. Nirken et all. Steven-Johnson Syndrome and Toxic Epidermal Necrolysis : Pathogenesis, Clinical manifestations and diagnosis, MD Employee of UpToDate Inc , Feb 2015

27. Harr Thomas, French LE. Toxic epidermal necrolysis and stevens Johnson syndrome. Dalam: Orphanet Journal of rare disease 2010:1-11

28. Mahadi IDR. Sindroma Stevens Johnson. Dalam: Simposium dan Pelatihan "What's new in Dermatology". Banda Aceh, 10 Juli 2010; 1-5

29. Torres MJ, Mayorga C, Blanca M. Nonimmediate Allergic Reactions Induced by Drugs: Pathogenesis and Diagnostic Test. Dalam: J Investing Allergol Clind Immunol 2009;19:8090

30. Maja Mockenhaupt, MD, PhD. The Current Understanding of Steven Johnsos Syndrome and Toxic Epidermal Necrolysis. Expert Rev Clin Immunol 7 (6), 803 - 815 ( 2011 )

31. Tyagi S, Kumar S, Kumar A, Singla M, Singh A. Stevens Johnson Syndrome-A life threatening disorder: A review. Dalam: J Chem Pharm Res 2010,2(2):618-26

32. Yim H, Park JM, Suk Kong, Kim D, Hur J, Chun W, et all. A clinical study of stevens Johnson syndrome and toxic epidermal necrolysis: Efficacy of treatment in Burn Intensive care unit. Dalam: J.Korean Surg Soc: 2010(78):133-39

Jurnal Averrous Vol.5 No.1 Mei 2019 
33. Ho, H. Diagnosis and management of stevens johnsosn syndrome and toxic epidermal necrolysis. Dalam: Hongkong Medical Bulletin;2010 Vol.13 No 10.

34. Whitney A High, MD et all. Steven Johnson Syndrome and Toxic Epidermal Necrolysis : Management, Prognosis and Long term sequelae. MD Employee of UpToDate Inc, March 2015

35. Michaels B, Q James. The role of systemic corticosteroid therapy in erythema multiforme major and stevens Johnson syndrome. Dalam: Clinical Aesthetic Dermatology;2009;2:51 55

36. Widgerow DA. Toxic epidermal necrolysis-management issues and treatment options. Dalam: Int J Burn Trauma; 2011;1(1);42-5 